\title{
INVESTIGATION OF A SINTERFORGING PROCESS FOR RADIALLY PARTICLE REINFORCED SINTERED MMC-COMPONENTS
}

\author{
Bernd-Arno BEHRENS, Irfan Yousaf MALIK, Ingo ROSS \\ Leibniz Universität Hannover, Institute of Forming Technology and Machines, Garbsen, Germany, EU, \\ ross@ifum.uni-hannover.de
}

https://doi.org/10.37904/metal.2019.758

\begin{abstract}
The ever-increasing demand for weight reduction of manufactured parts is leading to the replacement of steel with light metals such as aluminum and magnesium. However, light metals are at times unable to withstand high tribological, thermal or mechanical loads. This leads to an application of metal-matrix-composites (MMC) that possess the advantages of light metals (low weight and high ductility), as well as the characteristics of the reinforcing phase (high hardness, high strength and good wear resistance). To manufacture the MMC components, metal powders were shaped in a pressing process and further densified during a subsequent sintering phase. The residual porosity within the produced parts can be reduced by means of a subsequent sinterforging operation.

In this paper, cylindrical partially particle-reinforced specimens, with a radially layered structure, were manufactured by two-sided powder pressing and sintering. A subsequent forging operation was carried out to eliminate the minimal porosity. Different process parameters (forming temperature, true strain and dilation rate) were varied to investigate their effects on the density and structural bonding of the partially particle-reinforced material system. Therefore, the sinterforging process upsetting was carried out. Subsequently, the particlereinforced parts were characterised by metallographic analysis and hardness measurements. The results show that cracks and defects in the layer system of partially particle-reinforced powder compacts can be repaired using sinter forging.
\end{abstract}

Keywords: Powder metallurgy, aluminum, metal-matrix-composites, sinterforging

\section{INTRODUCTION}

Due to steadily rising material costs and demands on the global market, manufacturing companies are constantly trying to optimize their production processes. Alternative methods are investigated to gain better material properties, weight or cost reduction.

\subsection{Powder metallurgy}

Powder metallurgy (PM) competes directly with manufacturing processes such as casting, forming and machining. The powder metallurgy enables variable alloy formations and component design, not feasible with melt metallurgical processes [1]. It offers high material utilization, net-shape parts and low energy consumption $[2,3]$. Furthermore, PM processing is a very efficient way for mass production of small structural components and provides a wide range of different industrial applications. Common fields for PM components are aerospace, automotive, medical technology, household and sports equipment $[4,5]$.

The most frequently used industrial process for shaping sintered components is die pressing [4]. The cohesion of the pressed powder is achieved by mechanical clamping and cold welding of individual powder grains [6]. After filling the matrix, grains are compacted. First, the particles are rearranged, resulting in the collapse of bridges and filling of cavities. With increasing pressure, particle contacts increase due to the plastic deformation of powder grains. With further increase in pressure, particles whose deformation capacity is exhausted are broken and fill cavities, thus achieving a relative density of more than $90 \%$. The relative density 
$\rho_{\text {rel }}$ is defined as the ratio of the density of porous material $\rho_{\text {por }}$ to the density of fully compacted material $\rho_{0}$ as provided in equation (1).

$\rho_{r e l}=\frac{\rho_{\text {por }}}{\rho_{0}}$

The so-called green compacts retain their shape due to clinging and cold welding of the powder grains to each other [7]. In order to facilitate the sliding of individual powder particles, the so-called pressing aids, such as waxes, are added to powder before pressing. They enable a strong compaction of the powder when pressing the green compact and thus lower the porosity of the components $[4,8]$.

\subsection{Metal-Matrix-Composites}

Another advantage of PM is the possibility of adding reinforcement elements such as ceramic particles (e.g. $\mathrm{SiC}, \mathrm{TiC}$ ) or short fibres to improve mechanical attributes of the produced parts. These so-called "Metal-MatrixComposites" (MMC) enabled the production of high strength and rigid materials, which also possess comparatively low density. Further advantages result from increased wear resistance even at higher temperatures $[9,10]$. In addition, the reinforcement material can be placed in the desired area, providing increased functionality while saving resources. Due to resulting lightweight construction potential, these materials are mainly used in the aerospace and automotive industries [11]. However, the manufacturing of such functionally reinforced materials by conventional powder pressing and sintering can lead to an undesired density distribution and locally increased residual porosity.

\subsection{Sinterforging}

A significant reduction of porosity in the PM-components can be achieved by sinterforging, i. e. postcompaction of sintered bodies at elevated temperatures. Thümmler already presented this process in 1972 as hot post-pressing [12]. With strong plastic deformation of sintered components, $100 \%$ theoretical density can be reached. By increasing material density, clear improvement of the mechanical characteristics is achieved. Sinterforging of partially reinforced PM-parts raises different challenges, and therefore there is only a handful of studies in this field [13]. In particular, a coaxial arrangement of the different phases results in both axially and radially varying densities and has not yet been investigated. Thus, the aim of this study is to investigate the specific forming behaviour and the mechanical material properties of partially reinforced parts during sinter forging in order to be able to produce flawless components with a radially graded material system and adequate mechanical properties.

\section{PRODUCTION AND FORGING OF THE SEMI-FINISHED WORKPIECES}

For the experimental investigation, spherical shaped Alumix 123 (aluminum powder with $4.5 \mathrm{wt} \%$ copper, $0.6 \mathrm{wt} \%$ silicon and $0.5 \mathrm{wt} \%$ magnesium) was used as matrix material. Milled titanium carbide (TiC) powder was used as reinforcement phase. Compared to metallic materials, TiC has a particularly high hardness of $3200 \mathrm{HV}$ and a high melting temperature of $3160^{\circ} \mathrm{C}$. Its density is given as $4.9 \mathrm{~g} / \mathrm{cm}^{3}$ [14]. The particle size of titanium carbide proves to be fine-grained and the particle shape is sharp-edged due to the manufacturing process. Compared to the average particle size of matrix material of $60 \mu \mathrm{m}$, TiC particles with $20 \mu \mathrm{m}$ are significantly smaller. The material properties of the powders are displayed in Table 1.

Table 1 Properties of the powder material

\begin{tabular}{|c|c|c|c|c|c|}
\hline Material & Density & Production & Hardness & Particle Size & Shape \\
\hline Alumix 123 & $2.8 \mathrm{~g} / \mathrm{cm}^{3}$ & Gas atomized & $100 \mathrm{HV}$ & $60 \mu \mathrm{m}$ & Globular \\
\hline $\mathrm{TiC}$ & $4.9 \mathrm{~g} / \mathrm{cm}^{3}$ & Milled & $3200 \mathrm{HV}$ & $20 \mu \mathrm{m}$ & Sharp-edged \\
\hline
\end{tabular}


For manufacturing of the powder compacts, a two-sided uniaxial pressing tool-system was used. It consists of an upper and two lower stamps, which enable the pressing of radial reinforced powder compacts. The upper stamp and the outlying lower stamp have a diameter of $36 \mathrm{~mm}$. The inner lower stamp has a diameter of $24 \mathrm{~mm}$. For carrying out the pressing process the hydraulic multi axis press HPM 200 E2 was used (manufacturer: SMS-Meer). For performing the compaction of the radial reinforced powder compacts at first the outlying stamp was used as a die, the other stamps were pre-compacting the Alumix 123 powder. Afterwards the outlying stamp was moved downwards and the resulting space was filled with Alumix 123 powder or reinforced MMC-powder (TiC weight-proportion of $5 \mathrm{wt} \%, 20 \mathrm{wt} \%$ ). The final compaction movement was carried out by moving all stamps inwards. Finally, the radial partially reinforced compact was ejected. The powder pressing process stages are shown in Figure 1.

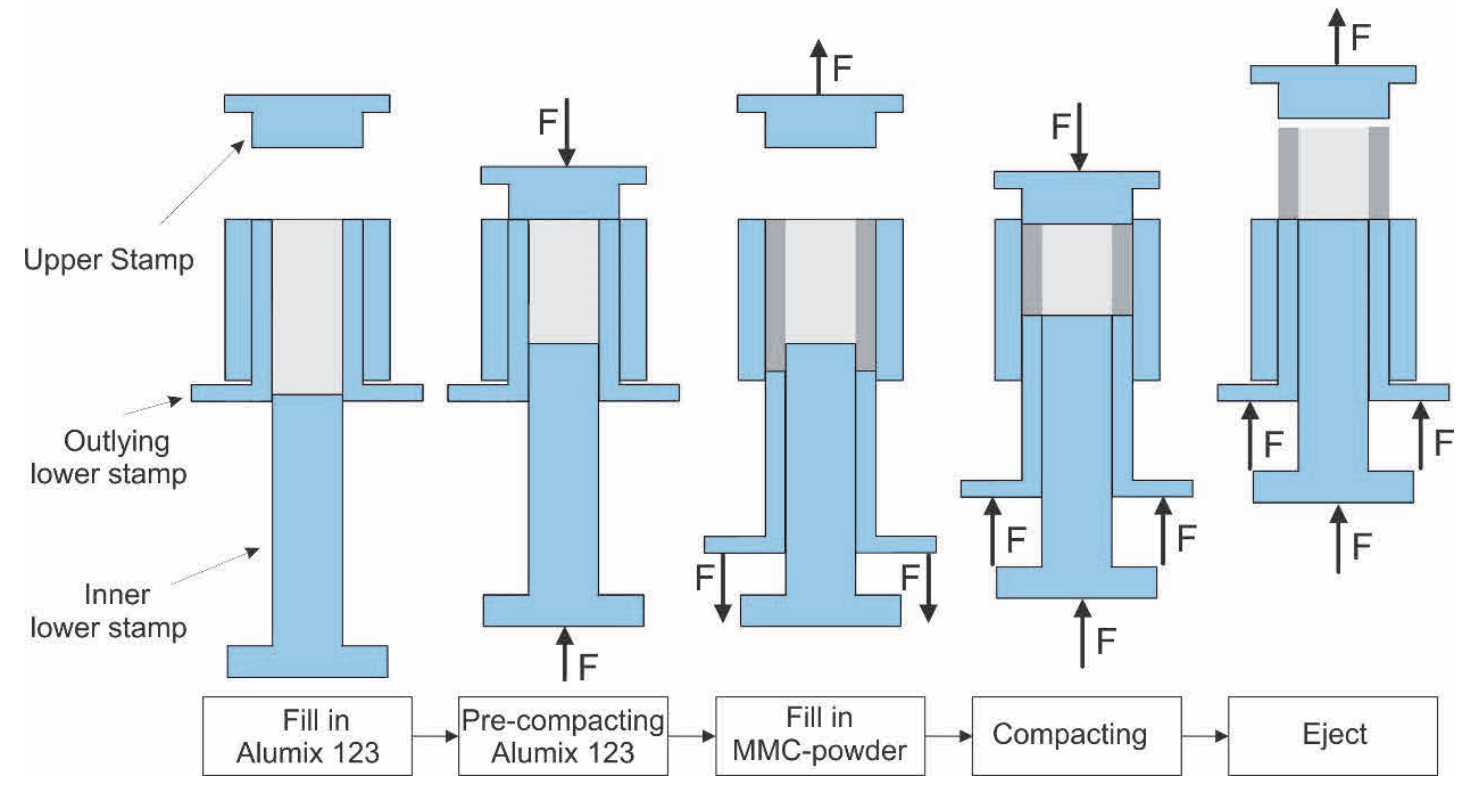

Figure 1 Stages of the powder pressing process

Sintering was carried out following the pressing process. For this purpose, the compacts were heated to 590 ${ }^{\circ} \mathrm{C}$ for 20 minutes under vacuum conditions. Subsequently, the sintered cylindrical radially reinforced work pieces were forged with material flow by an upsetting process on a servo-hydraulic forming simulator (manufacturer: Instron). The parameters of the forging operation are shown in Table 2.

Table 2 Parameters for the sinterforging operation

\begin{tabular}{|c|c|c|c|}
\hline TiC phase $(\mathrm{wt} \%)$ & Temperature $\left({ }^{\circ} \mathrm{C}\right)$ & True strain & Dilation rate (1/s) \\
\hline $0,5,20$ & 300 & 0.6 & 10 \\
\hline
\end{tabular}

\section{CHARACTERISATION OF THE FORGED WORKPIECES}

The results presented below focus on investigations with the following forging parameters: a temperature of $300{ }^{\circ} \mathrm{C}$, a dilation rate of $1 \mathrm{~s}^{-1}$ and a true strain of 0.6 .

Metallographic images were used to investigate the material properties of the sintered concentric components. Therefore, the samples were cut in the middle before and after the upsetting process. The metallographic images enable an evaluation of the influence of the sinterforging process on sintered powder compacts.

In Figure 2, the metallographic images of specimen without reinforcement are displayed. On the left, the sintered green part is shown. Here a side effect of this newly developed powder pressing process becomes 
apparent. An inhomogeneous powder pressing process caused cracks to form in the sintered parts. Finally, the outer powder was compacted and exerted pressure on the inner pre-compacted powder, which was thereby narrowed.

Figure 2 shows on the right side the sinterforged specimen. Due to the powder-metallurgic process route, the gap between the aluminum and the particle-reinforced could be closed completely by the upsetting operation at $300{ }^{\circ} \mathrm{C}$. Furthermore, a transition zone within this specimen was undetectable in metallographic investigations following the forging operation, which suggests very good material cohesion.

\section{Specimen with $0 \% \mathrm{TiC}$}
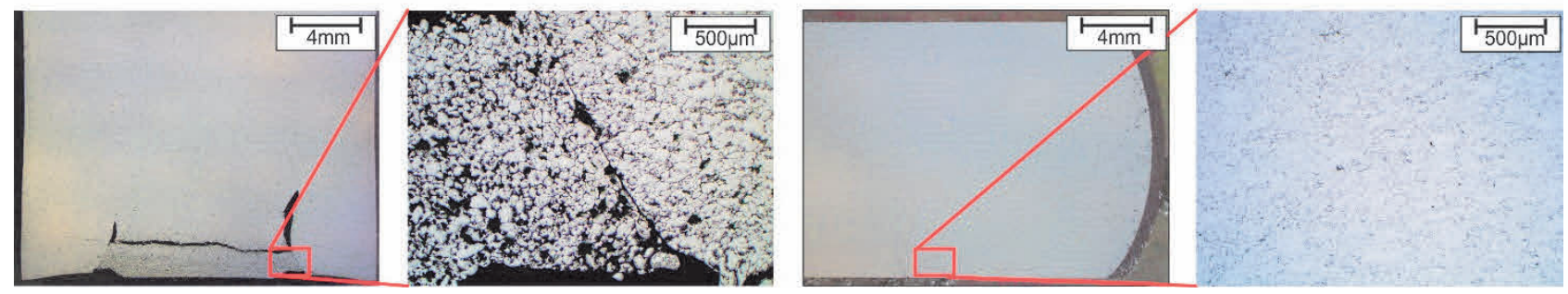

Figure 2 Metallographic analysis of specimen with $0 \% \mathrm{TiC}$ before (I.) and after (r.) sinterforging at $300{ }^{\circ} \mathrm{C}$

Figures 3 and 4 show specimens with 5 wt\% and 20 wt\% TiC reinforcement before and after sinterforging. On the left side a crack produced in pressing process is visible. It was possible to close the crack by means of the pressing process at $300{ }^{\circ} \mathrm{C}$. Metallographic pictures show clear phase transitions between the core and the reinforced part of the specimen.

\section{Specimen with $5 \%$ TiC}
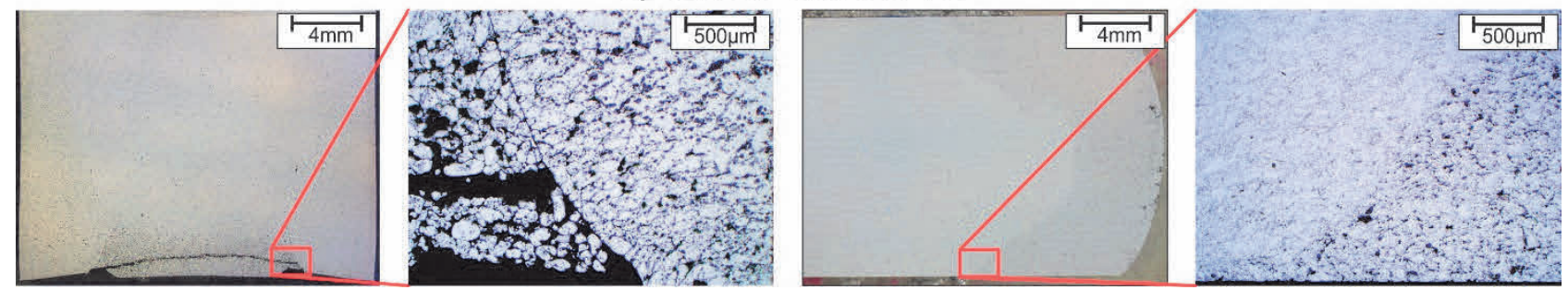

Figure 3 Metallographic analysis of specimen with 5 wt\% TiC before (I.) and after (r.) sinterforging at $300{ }^{\circ} \mathrm{C}$

Specimen with $20 \%$ TiC
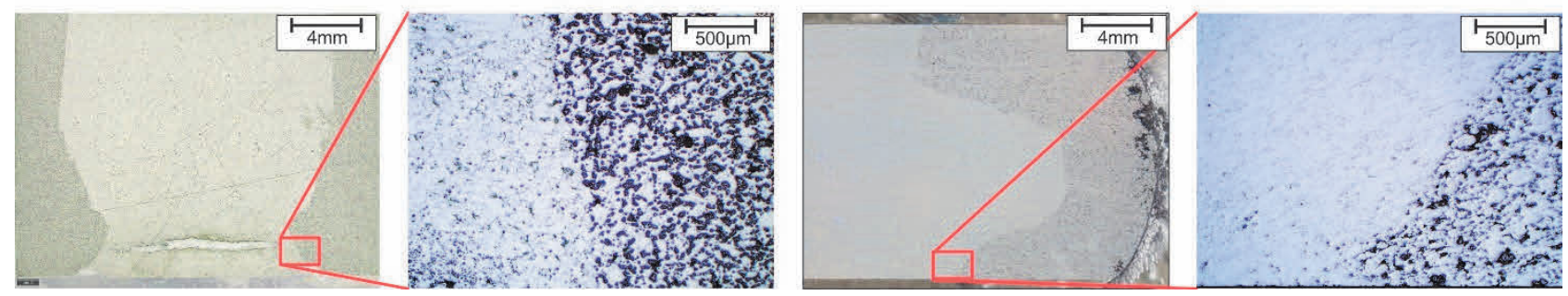

Figure 4 Metallographic analysis of specimen with 20 wt\% TiC before (I.) and after (r.) sinterforging at $300{ }^{\circ} \mathrm{C}$

After sinterforging operation, the unreinforced areas seemed to be mostly homogeneous, i. e. they were almost free of pores. In comparison, the reinforced areas were permeated with irregularities, which were partly TiC particles, but also pores. Especially the area reinforced with 20 wt\% TiC showed a significant increase in quantity and diameter of visible pores and defects. 


\section{MATERIAL PROPERTIES OF THE SINTERFORGED COMPONENTS}

Due to influences on the material properties, an investigation of the porosity was carried out. Based on the metallographic analysis the pore volume was measured with a Matlab-based software. This software allocates the metallographic images to the different areas aluminum, TiC and pores based on an optical inspection. Five determined areas were investigated as shown in Figure 5. Area 1 represents the middle of the specimen with the lowest expected porosity. Area 2 and 3 represent the not reinforced area next to the transition phase of the specimen. Area 2a and 3a represent the reinforced part.

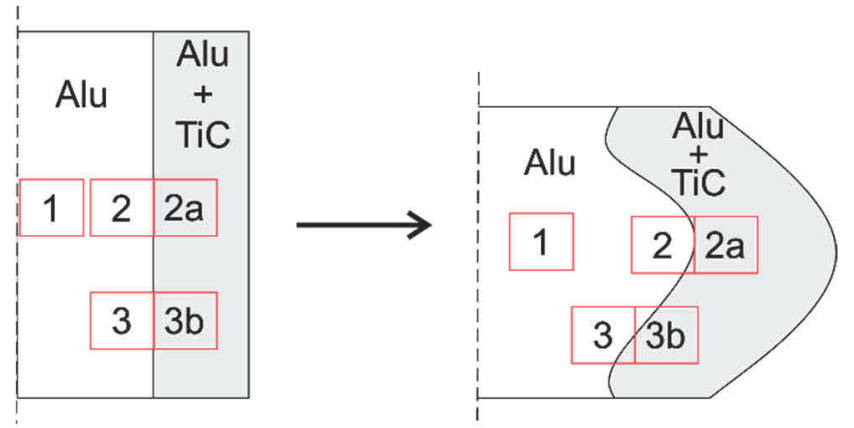

Figure 5 Reinforced Specimen before (I.) and after (r.) sinterforging

Figure 6 shows the existing porosity within the specimens before and after sinterforging according to the division areas shown in Figure 5. The sample without particle reinforcement had an initial void volume fraction of about $2 \%$ before sinterforging. After the upsetting process, the investigated areas showed a nearly complete compaction of under $1 \%$ porosity.

Samples with particle-reinforcement also showed significant reduction of porosity after sinterforging. Within the aluminum phase, a significantly fewer porosity occurred before and after sinterforging. Since the reinforcing phase acts as an obstacle and cavities form around it, it can be argued that the addition of reinforcing particles (i.e. TiC in this case) led to a higher porosity. Therefore, a content exceeding $20 \mathrm{wt} \%$ TiC should to be avoided.
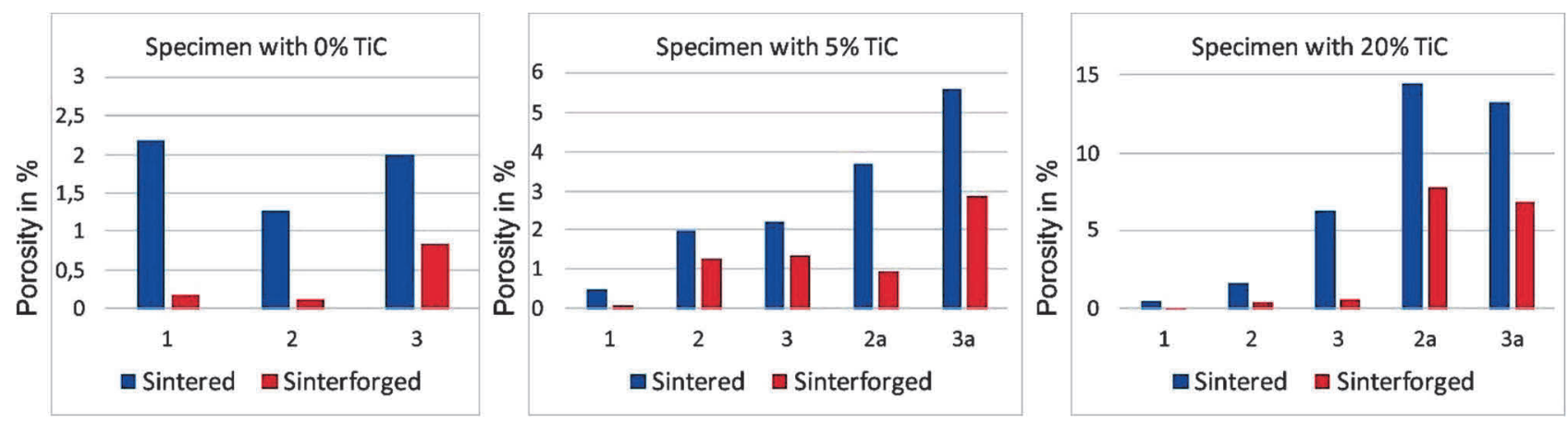

Figure 6 Porosity of the specimens before and after sinterforging

\section{CONCLUSION AND OUTLOOK}

Within this study, sinterforging of cylindrical radially reinforced powder compacts produced by two-staged powder pressing was investigated. For the semi-finished work pieces, aluminum with and without radially reinforcement of ceramic powder $(\mathrm{TiC})$ content was pressed followed by sintering in vacuum at a temperature of $590{ }^{\circ} \mathrm{C}$ for 20 minutes. Subsequently, semi-finished work pieces were forged at varying temperatures with a material flow by an upsetting process. 
The results of the investigations prove that it is possible to manufacture radially reinforced compacts by conventional powder pressing. Cracks occurring during powder pressing can be repaired in sinterforging. Sinterforging also allows the porosity to be decreased significantly.

\section{ACKNOWLEDGEMENTS}

The results presented are based on the framework of the research project "Hot Forging of partially particle-reinforced sintered components" under the project number 283970253. The authors would like to thank the German Research Foundation (DFG) for financial support.

\section{REFERENCES}

[1] ESPER, F. J. Pulvermetallurgie. Das flexible und fortschrittliche Verfahren für wirtschaftliche und zuverlässige Bauteile ; mit 15 Tabellen. Renningen-Malmsheim: Expert-Verl., 1996. Kontakt \& Studium. Bd. 494. 9783816913214.

[2] BEHRENS, B.-A., BONHAGE, M., CHUGREEV, A., ROSS, I. and MALIK, I. Numerical Investigation Of A Hot Forging Process For Partially Particlereinforced Sintered Components. In Conference Proceedings of the 27th International Conference on Metallurgy and Materials (METAL2018), 23-25 May, Brno, 2018. pp. 330-335.

[3] BEHRENS, B.-A., GASTAN, E., VAHED, N. and LANGE, F. Numerical analysis of the process chain for the production of PM components with integrated information storage. In: BEHRENS, B.-A., GASTAN, E., VAHED, N., LANGE, F. Production Engineering - Research and Development. 4th ed. Garbsen: Springer-Verlag, 2010, pp. 477-482.

[4] SCHATT, W., WIETERS, K.-P. and KIEBACK, B. Pulvermetallurgie: Technologien und Werkstoffe. 2nd ed. Berlin: Springer Press, 2007, p. 540.

[5] SANDER, C., RATZI, R., LORENZ, B. and TOBIE, T. Sintered Gears - Achievable Loaded-carrying Capacities by Conventional and New Production Methods. In: International Conference on Gears. 2002. vol. 1, pp. 295-310.

[6] GASTAN, E. Einfluss von Werkzeugschwingungen auf das Verdichtungsverhalten metallischer Pulver beim Matrizenpressen. Dissertation. Garbsen: IFUM, Leibniz Universität Hannover, 2011.

[7] BEER, O. Verdichtung von Metallpulvern. In: BEER, O. Fortschrittberichte VDI. Düsseldorf: VDI Verlag.1996. vol. 458.

[8] DEGISCHER, H. P. and LÜFTL, S. Leichtbau - Prinzipien, Werkstoffauswahl und Fertigungsvarianten. 1st ed. Weinheim: WILEY-VCH Verlag, 2009.

[9] BEHRENS, B.-A., KOSCH, K.-G., FRISCHKORN, C., VAHED, N. and HUSKIC, A. Compound forging of hybrid powder-solid-parts made of steel and Aluminum. Key Engineering Materials. 2012. vol. 504-506, pp. 175-180.

[10] BAO, C.G, WANG, E. Z., GAO, Y.M. and XING, J.D. Effect of volume fraction of particle on wear resistance of $\mathrm{Al}_{2} \mathrm{O}_{3} /$ Steel composites at elevated temperature. Journal of Iron and Steel Research International. 2005. vol. 12, pp. 60-63.

[11] SHIMIZU, Y. and NISHIMURA, T. Corrosion resistance of Al-based metal matrix composites. In: LAVERNIA, E. J. Materials Science and Engineering: A. 1995. vol. 198, pp. 113-118.

[12] THÜMMLER, F. New developments in powder metallurgy. Zeitschrift für Werksstofftechnik. Weinheim: Verlag Chemie GmbH, 1972. vol. 8, pp. 394-414.

[13] RASSBACH, S. Grundlegende Untersuchungen zum Umformverhalten von Gradientenwerkstoffen unter Anwendung von Druckumformverfahren, Dissertation, TU Bergakademie Freiberg, 2002.

[14] BARGEL, H.-J. and SCHULZE, G. Werkstoffkunde. Heidelberg Dordrecht London New York: Springer-Verlag, 2012. vol. 11, p. 377. 